\title{
An Appeal for More Research on Individual Language Guidance
}

\begin{abstract}
Although it constitutes a quite popular and effective system of foreign language teaching/learning, language tutoring seems to be disregarded in academic work as well as in teaching materials. Yet, a specific structure of tutoring offers an attractive field for the research that cannot be conducted in the context of group learning. Results of the research could not only enhance the current state of glottodidactic knowledge, but also extend the methodological base, in which it is now futile to search for instruction on the individual work with the learner. The present article is thus an attempt to begin an academic discussion concerning language tutoring.
\end{abstract}

KEYWORDS: language tutoring, individual language guidance, glottodidactic process, learner autonomy, teacher educational roles.

In the face of the scanty amount of scientific material dedicated to the subject of language tutoring, this article aims to prove that there exist many justifications of the need to expand research on the quality of language training in the system of individual lessons. After providing the reader with the definition of language tutoring and contrasting the unbalanced popularity of this model among its users and investigators, the paper is going to discuss four chosen areas of exploration of individual language guidance in order to show the research potential present in this model of language teaching/learning.

\section{WHAT IS LANGUAGE TUTORING?}

Individual lessons with the tutor are usually referred to in Polish as 'private lessons', 'individual lessons' or - less frequently - 'tutoring', the latter being usually associated with teaching at the university level. A definition 
suitable for this article is proposed by Katarzyna Czayka-Chełmińska (2007: 38), who describes it as 'a planned process of development' [all the citations from Polish translated by the Author]. What is more, this development 'occurs in an individual, supportive relation with the other person - the tutor' (loc. cit.).

What is especially interesting for glottodidactics in the above definition is such an approach to the commonly understood 'lessons one-to-one with the teacher' which aims at student autonomy. Moreover, together with the change of perspective there appears a change in the identification of the teacher's role, who, as Ewa Korulska (2007: 86) puts it, becomes 'a coach'. Both authors discuss tutoring as a form of coaching in the context of training for leaders; hence, for the purpose of this article, which is focused on glottodidactic issues, it is necessary to adapt the existing definition. I would like to propose the following explanation of a system of individual lessons (further called 'tutoring' or 'individual language guidance/training'), which - in the context of foreign language teaching - may be understood as:

a model of language training based on one-to-one work of the teacher and the student, of which the goal is to equip the student with skills that will help him/her to independently lead his/her further language development.

The Author's abovementioned definition is meant to include such issues as

- 'inside-outside' character of the glottodidactic process (Figarski 2003: 24-27) which targets at student autonomization (for learner autonomy see: Holec 1981; Little 1991; Benson 2000; Little 2003; Lamb, Hayo 2008);

- the constructivist idea of 'extracting language from the student', co-producing this language with the help of the teacher-animator (see: Lewicka 2007);

- educational roles of the teacher/tutor (see: Wright 1987; Korpaczewska 2004; Harden, Crosby 2000);

- factors influencing the effectiveness of tutoring, with special regard to teacher and student individual traits (Robinson 2002; Figarski 2003: 93-102).

As explained above, language tutoring is such a form of foreign language guidance in which the relation teacher-student is just a starting point and the teacher's and the student's roles are by design flexible and constantly negotiated. This flexibility of the teaching model consists of matching teaching techniques to the student's learning preferences (conditioned by the learner's individual traits), thereby allowing the student to co-design the enhancement of his/her language competence.

It should be underlined that the interpretation of the notion 'tutoring' that has just been given does not belong only to the domain of individual private education. While it is true that from a statistical point of view teaching through tutoring is more commonly found in the private education sec- 
tor, one cannot forget that elements of tutoring - unfortunately not numerous - appear also in public schools in the form of, e.g. individual courses for gifted students, courses for the ones with special educational needs (or staying at home because of long-term health-related problems) or academic tutoring (the supervisor's guidance of the student writing his/her BA or MA thesis).

\section{THE POPULARITY OF INDIVIDUAL LANGUAGE TRAINING}

According to the data from a report by the European Committee from 2011, 49\% of Polish students who have private lessons seek them among teachers: in $10 \%$ of the cases the tutor is the same person who teaches the student at school, in $8 \%$ it is a teacher employed in this school, and in $31 \%$ a teacher from a different school (Eopina 2011). These data indicate a wide interest in extramural courses of individual foreign language training led by professionals. Furthermore, as Elżbieta Putkiewicz asserts, the demand for private lessons is saturated by its supply (Putkiewicz 2005: 3), which in turn implicates 'a series of negative pedagogical, social, ethical and economical consequences' (Putkiewicz 2005: 2).

The phenomenon described by Putkiewicz as a 'grey zone of education' undoubtedly has an important impact on the listed areas of social life, which is why the fact that it remains a taboo surprises even more. Nevertheless, the present article concentrates on a different query, which is the lack of sufficient research on individual language guidance as seen from the glottodidactic perspective.

\section{THE CURRENT STATE OF RESEARCH ON TUTORING}

In 1987 Peter Wilberg, the author of the tutoring coursebook "One to one: A teacher's handbook", observed that even though the rules of individual training can fit any learning context, it is the least exploited subject in language teaching theory (Wilberg 1987: Introduction, n. pag.). Unfortunately, although the state of research on tutoring in English-language literature has been slightly enhanced from the time of Wilberg's publication (see: Chi et. al. 2001; Trotter 2004; Chi et. al. 2008), among Polish glottodidactic works it is futile to seek greater concern about this problem. Also, it is difficult to find an unequivocal reason for this. Is it because they took it for granted that teachers of individual courses can (or even should) learn from courses written from the perspective of teaching groups? Or perhaps this particular field of the research does not encourage a neophilological environment because of 
- in most cases private - the nature of these courses? In other words, does the academic environment assume that their duty is to look for ways on how to improve the quality of teaching only in public schools? These questions obviously cannot be answered at this moment.

\section{BENEFITS OF THE RESEARCH ON LANGUAGE TUTORING}

Assuming that the teacher plays essential role in the process of language education (see: Figarski 2003; Sobkowiak 2009), one cannot object that it is only natural that he/she should have access to reliable sources of information and tips which may improve his/her professional qualifications. Meanwhile, the current conditions in Poland make this access in terms of tutoring seem quite difficult. Sceptics, who do not see the need for publications on this matter, may argue that the teachers conducting individual lessons have course books and methodological materials for group teaching at their disposal, so they just need to know how to use them. However, such an answer is not satisfactory, especially when we consider the issues related to the students' communicative activeness, such as attempts to build their own utterances and participate in authentic communication (conversation with the teacher). As Wilberg assures (1987: Introduction, n. pag.), 'it is not very helpful to use course books with instructions such as Get the students to stand in a circle'. It is not only about the teacher's comfort. In the further part of his argumentation supporting work on tutoring, Wilberg (1987: Introduction, n. pag.), warns that the implementation of the exact same knowledge which concerns teaching a foreign language in the classroom may both have a difficult and dangerous bearing for tutoring. What he tries to achieve surely is to sensitize teachers and researchers to the negative results of a unified attitude to learners, which not only questions the effectiveness of the learning process, but also contradicts the constructivist idea of the mode of language training which is directed to develop learner autonomy (see: Wilczyńska 2001; Lewicka 2007). Thus, it appears logical that there is a visible gap in materials on the didactics of foreign languages which could help the teacher to promote the student's language growth, without depriving him/her of the opportunity to learn according to the principles of an approach which is nowadays considered to be one of the most effectual, that is the constructivist approach.

Despite the fact that the lack of supportive materials on language tutoring negatively influences the development of the teacher's basic knowledge about this teaching context and hinders the design of the teaching plan, ad- 
ditionally such status quo limits the sources of support in problematic situations. Admittedly, there is the possibility to seek advice from a tutor-mentor (in the case of an educational institution) or an acquaintance of the same profession (in the case of self-employed tutors), yet the significant difference between the situation of a tutor and a teacher who teaches groups is that the tutor does not have the opportunity to use the presence of an objective observer as a source of feedback and tips. Unluckily, such a tutor can rely only on himself/herself and the only help he/she can get comes from selfassessment (see: Sobkowiak 2009). So, it seems even more obvious that researchers ought to prepare publications which might help tutors to find a proper application of constructive self-reflection.

Another argument for the intensification of research on the process of individual language guidance is a matter equally crucial as the support for tutors, and that is an attempt to improve the situation of the learner. If we consider the strength of the impact of content-related, methodological and pedagogical competences of the teacher on the learning process (Wilberg 1987: 2-9; Figarski 2003: 93), we may conclude that it is the learner who is the major recipient of the benefits (or the lack thereof) stemming from the changes in the level of these competences. A strong double-edged bond between the tutor and the student causes that every refinement in the training process will trigger an advantage for both participants of the glottodidactic process.

In addition to this, it is worth mentioning in what way glottodidactics might benefit from the exploration of the research field presented above. A question that may arise is to what extent language tutoring is a promising area of investigation, or, to be more precise, to what degree it is a sufficiently complex and cognitively attractive field of inquiry.

The first argument for the usefulness of an individual system of language training is connected with its unique character. It is a teaching/learning context which provides investigators with material for this kind of research which could not be conducted in a group learning setting. Moreover, a specific structure of individual language guidance constitutes an ideal space for empirical verification of the theories related to the three problems listed in the beginning of this article: the problem with the autonomisation of language acquisition, the impact of personality-related factors on the glottodidactic process and the teacher's educational roles. Also, language tutoring allows us to examine the effectiveness of some techniques of teaching foreign languages (e.g. techniques which involve the use of the latest technology). More information on the utility of individual language training in these four research areas will be described below. 


\subsection{Language tutoring and research on learner self-development}

Let us begin from the possibilities which language tutoring can offer researchers interested in the problem of learner autonomy, which has become one of the most important issues of contemporary teaching (Little 1991: 3). The first very important advantage of individual language guidance lies in providing conditions beneficial for reaching the aim of autonomisation. Starting from the issue of one's responsibility for the effects of the teaching/ learning situation, in tutoring it becomes clear that it belongs in the same degree to the teacher and the learner. Thus, tutoring fulfils the crucial requirement of learner autonomy to take place, which, as Little (2003: 4) claims, is the learners' realisation of their impact on the course of their own development, supported by the opportunity to exercise this role.

Although one may think that the division of responsibility is understood in exactly the same way as in the case of group learning, we cannot forget that tutoring means more comfort for both sides and considerable elimination of the factors negatively influencing the pace and the quality of the teacher's and the students' work (to list only few: lack of noise, maximum level of the subjects' attention, better economy of the lesson time (not disturbed by organisational or disciplinary issues) and easier access to the latest technology supporting teaching and learning). As a consequence, there are fewer and fewer factors which the teacher or the student may blame for their own failures. Such an arrangement induces a heightened self-control of both subjects. Thanks to this the teacher's and the student's systematic selfevaluation may incline them to draw appropriate conclusions and improve the quality of their teaching/learning.

Another trait of language tutoring useful for the research on building learner autonomy is that it involves better conditions for a conscious setting of the educational aims. As Figarski (2003: 24) maintains, establishing clear targets at the initial, 'entry' stage of the glottodidactic process is crucial for achieving success at the 'exit' stage. What is more, Figarski (2003: 24) emphasises also the meaning of the factors such as the possibility of realizing the aim, the state of the student's competence and personality determinants. So, here we can notice other advantages that tutoring has over group teaching/learning, namely the opportunity to genuinely get to know the learner and to have the chance for re-expression of the teaching/learning aim (in case there is a need to do this).

If we talk about the process of autonomisation, it is worth noting that tutoring, which by definition assumes individualisation of the glottodidactic process, is flexible enough to provide the learner with a way of teaching which is tailored to the individual's needs: internal, such as a preferable learning style and techniques, and external, such as training of a given lan- 
guage skill or a set of skills (for instance emphasis on improving oral communication skills or reading comprehension) or focus on a specific field (like Business English). Consequently, the student gains control over the process of teaching/learning and becomes its active participant not only through being engaged in a lesson, but also by having an impact on the organisation and the structure of the whole process. It is exactly what Nunan (1987: 2) the advocate of learner-centred curriculum - expects when he says that 'the curriculum is a collaborative effort between teachers and learners'. In this way the student learns how to single handedly make rules of his/her own educational path, or, to put it differently, he/she learns autonomy (Wilczyńska 2001: 36). Additionally, as self-determination is nothing less than marking one's subjectivity, it means that this kind of learning should be welcomed by students who, in Figarski's view (2003: 120), 'appreciate consciousness of their own subjectivity, individual ways (secrets) of learning, fair grades, perceive the meaning of self-control and self-assessment'.

Furthermore, learning a language in a one-to-one model supports learner autonomy also because of the presence of the teacher, who is viewed as the controller of the student's work and who constantly promotes the learner's activity. Besides, it is quite probable that the situation would be different (to the student's disadvantage) if he/she had to work by himself/herself (Wilczyńska 2001: 37).

The next positive quality of language tutoring which makes it a suitable model for the research on learner self-development is the advantageous pattern of the tutor-student relationship. It is a common fact that a positive and more indirect relationship between the teacher and the student has a profitable bearing on breaking the language barrier and decreasing negative emotions (like stress or anxiety) connected with the situation of using the second language. In light of this opinion one cannot deny that tutoring enables the appearance of such a valuable interpersonal relation far more likely than learning in groups. It composes an ideal ground for starting and continuing the authentic dialogue (see: Figarski 2003: 173-174), which is not easy, definitely time-consuming and demands much of the teacher's attention, supporting the learner's speech and providing him or her with continuous feedback, for which there are no conditions in a crowded school classroom.

\subsection{Language tutoring and the effectiveness of some ESL teaching techniques}

It may seem that if so much research on techniques of teaching L2 was carried out with the use of respondents learning in school groups, there is no need to duplicate it in a tutoring environment. Nevertheless, like in the case 
of autonomisation, it turns out that the model of individual language guidance gives opportunities for the realisation of such research purposes which in other circumstances are hampered by the presence of many variables obscuring the results. We can imagine for instance how easier it would be to examine the effect of watching films or podcasts with/without subtitles on the expansion of one's vocabulary or the impact of e-learning on the improvement of reading comprehension. Possibilities are numerous; we can still find poorly explored directions of inquiry for which language tutoring can offer good research conditions. An example of such examination of tutoring are works by M. T. H. Chi et al. (2001; 2008), who tested its efficacy comparing the utility of tutoring's components (the effect of the teacher, the student and the interactions between them on a positive result of teaching/learning) (Chi et. al. 2001) or differences in the efficiency of tutoring per se and observation of tutoring by the third person (who had also possibility of interaction with other observer) (Chi et al. 2008). The first of these investigations contributed to the enhancement of knowledge useful for the creation of ITS, i.e. Intelligent Tutoring Systems; the second proved a beneficial impact of 'listening to' tutoring in the classroom. A slightly similar interest in the comparison of tutoring with another teaching technique (unassisted work with text) was used by Lehn et al. (2007).

\subsection{Personality factors in language tutoring}

As highlighted in section 1, language tutoring is also a promising area of research on interrelations between particular personality factors and the effectiveness of the glottodidactic process. It is an attractive field for these researchers who are interested in psychological theories. While it is true that some of the aforementioned factors have already been described, yet, analogically to the situation of research on some profoundly examined teaching methods, also in the subject area of teacher and student individual traits one can find scientific niches. For example, one may investigate the correlation between the Myers-Briggs personality type of the learner and his/her favourite learning style (see: Moody 1988; Dąbrowska 2011) or the effect of the teacher's personality on his/her style of teaching and phenomena arising as a result of the clash of the teacher's and the student's different preferences. Other unresolved questions are: What happens when the teacher's and the student's types are highly contradictive? Who and in what way settles the conflict of needs caused by contrasting preferences of teaching and learning? What consequences does it have for the process of language training and learner self-development? These are just some of the possible queries which might be stated in the research on language tutoring. 


\subsection{Language tutoring as a field of research on the teacher's educational roles}

The significance of the teacher's educational roles for the overall result of the teaching/learning process has been widely examined in glottodidactics (see: Wright 1987; Harden, Crosby 2000; Korpaczewska 2004). Yet, the current knowledge of this matter predominantly concerns the group learning context. Another issue is checking the composition of the teacher's educational roles in a completely individualised model of learning. Hence, the combination of tutoring and learner autonomy prompts another set of questions: If and to what extent does the teacher let the learner negotiate the existing roles? How does domination of a given role influence the process of learning the language? What are similarities/dissimilarities in the distribution of the teacher's roles if we compare tutoring and teaching groups?

The place of educational roles in tutoring is remarkable, as in this quite specific educational model the teacher has a challenging task to encourage and equip the learner with tools that aid the self-creation of his/her language development. The teacher has to accustom himself/herself and the learner to a gradual change from the position 'learner-addressee' to the position 'learner-addresser', in other words the initiator of communication (Figarski 2003: 173). But it is not easy to reach such a level of competence when a badly fitted and habitually played teacher's educational role - precisely speaking, the role of 'controller' (see: Harden, Crosby 2000; Korpaczewska 2004), misusing instructive teaching style - impedes the learner's development (Lewicka 2007: 80). How often it happens and by what means we can solve this problem we may get to know through applying the glottodidactic perspective to language tutoring.

\section{CONCLUSIONS}

Ideas for investigation suggested above are the proof of the fact that individual language guidance is a good research area for inquiries which demand satisfying conditions such as the high level of individualisation of the teaching/learning process, the teacher's maximal focus on the learner (and vice versa) and a big degree of flexibility of the elements of the glottodidactic process. Surely in glottodidactics there might be other interesting problems which could use tutoring as a field of examination. The four that have just been explained are merely a makeshift of the subject area connected with language tutoring and its aim was to begin an academic discussion around this form of teaching/learning. 
Like it has been justified in the main part of this article, there are several quite important premises of the scientific potential of language tutoring that are worth noting in contemporary glottodidactics. In spite of the fact that the private sector, dominant in language tutoring, may seem like a remote area of interest for academic researchers, we should not forget that the system of individual courses is present in public schooling, though to a lesser degree; it may even appear in the highly specialised form of individual lessons with students with special educational needs, which poses a real challenge for teachers. Hence, it is even more needed to provide teachers with tips for good performance and further professional development within this model of teaching a second language. The responsibility of an applied science, which glottodidactics certainly is, is to contribute to the improvement of the quality of life regardless of social or economic divisions.

\section{REFERENCES}

Benson, P., 2000. Autonomy as a learners' and teachers' right. In: Sinclair, B., McGrath, I., Lamb, T. (eds). 2000 Learner autonomy, teacher autonomy: future directions. London: Addison Wesley Longman, 111-117.

Chi, M.T.H., Siler, S.A., Jeong, H., Yamauchi, T., Hausman, R.G., 2001. Learning from human tutoring. In: Cognitive Science: A Multidisciplinary Journal, 4, 471-533.

Chi, M.T.H., Roy, M., Hausman, R.G., 2008. Observing tutorial dialogues collaboratively: Insights about human tutoring effectiveness from vicarious learning. In: Cognitive Science: A Multidisciplinary Journal, 2, 301-341.

Czayka-Chełmińska, K., 2007. Metoda tutoringu. In: Kaczarowska, B. (ed.). Tutoring: W poszukiwaniu metody kształcenia liderów. Warszawa: Stowarzyszenie Szkoła Liderów, 38-43.

Dąbrowska, M., 2011. Rola różnic indywidualnych w aktywacji strategii uczenia się języków obcych. Część III. Cechy osobowości: Przegląd badań. In: Rozprawy Społeczne, 1, 135-145.

Figarski, W., 2003. Proces glottodydaktyczny w szkole. Warszawa: Wydawnictwa Uniwersytetu Warszawskiego.

Harden, R.M., Crosby, J.R., 2000. AMEE Education Guide No 20: The good teacher is more than a lecturer - the twelve roles of the teacher. In: Medical Teacher, 4, 334-347.

Holec, H., 1981. Autonomy and foreign language learning. Oxford: Pergamon Press.

Korpaczewska, I., 2004. Edukacja językowa w perspektywie ról nauczyciela. In: Janaszek, K., Gawarkiewicz, R. (eds). Glottodydaktyczne i kulturowe aspekty komunikacji jezzykowej. Szczecin: Wydawnictwo Naukowe Uniwersytetu Szczecińskiego, 95-105.

Korulska, E., 2007. Tutoring w edukacji szkolnej. In: Kaczarowska, B. (ed.). Tutoring: W poszukiwaniu metody ksztatcenia liderów. Warszawa: Stowarzyszenie Szkoła Liderów, 86-91.

Lamb, T.E., Hayo R. (eds), 2008. Learner and teacher autonomy: Concepts, realities, and responses. Amsterdam-Philadelphia: John Benjamins Publishing Company.

Lehn, K. van, Graesser, A.C., Jackson, G.T., Jordan, P., Olney, A., Rose, C.P., 2007. When are tutorial dialogues more effective than reading? In: Cognitive Science, 1, 3-62.

Lewicka, G., 2007. Glottodydaktyczne aspekty akwizycji języka drugiego a konstruktywistyczna teoria uczenia się. Wrocław: Oficyna Wydawnicza ATUT. 
Little, D., 1991. Learner autonomy: Definitions, issues and problems. Dublin: Authentik.

Little, D., 2003. Learner autonomy in the foreign language classroom: Taking account of all the roles and agencies involved in secondary education. In: Little, D., Ridley, J., Ushioda, E. (eds.). Learner autonomy in the foreign language classroom: Teacher, learner, curriculum and assessment. Dublin: Authentik.

Łopina, K.S., 2011. Czy nauka języków musi być tak bardzo droga? [Internet article] In: GazetaEdukacja.pl. http://edukacja.gazeta.pl/angielski/1,125340,10817745,Czy_nauka_jezy kow_musi_byc_tak_bardzo_droga_html (date of access: 15.08.2012).

Moody, R., 1988. Personality preferences and foreign language learning. In: The Modern Language Journal, 4, 389-401.

Nunan, D., 1987. The learner-centred curriculum. Cambridge: Cambridge University Press.

Putkiewicz, E., 2005. Korepetycje - szara strefa edukacji. In: Analizy i Opinie, 56, 2-6.

Robinson, P. (ed.), 2002. Individual differences and instructed language learning. AmsterdamPhiladelphia: John Benjamins Publishing Company.

Sobkowiak, P., 2009. Systematyczna samoocena własnej pracy nauczyciela jako element podnoszenia jakości kształcenia językowego. In: Pawlak, M., Mystkowska-Wiertelak A., Pietrzykowska A. (eds). Nauczanie języków obcych dziś i jutro. Poznań-Kalisz: Wydział Pedagogiczno-Artystyczny UAM w Kaliszu, 141-151.

Trotter, E., 2004. Personal tutoring: Policy $v$ reality of practice [material from the conference Education in A Changing Environment which took place 13-14.09.2004 in Manchester, UK]. Manchester: The University of Salford. http://www.ece.salford.ac.uk/proceedings/2004 (date of access: 29.07.2012).

Wilberg, P., 1987. One to one: A teacher's handbook. London: Language Teaching Publications.

Wilczyńska, W., 2001. Nauczać to rozwijać uczenie się, czyli o podejściu autonomizacyjnym w dydaktyce obcojęzycznej. In: Prokop I. (ed.). Materiaty I meetingu glottodydaktycznego zorganizowanego w ramach podyplomowego stadium glottodydaktyki 1999/2000. Poznań: Wydawnictwo Naukowe UAM, 35-46.

Wright, T., 1987. Roles of teachers and learners. Oxford: Oxford University Press. 
